\title{
Comparison of fish assemblages in two littoral habitats in a Neotropical morichal stream in Venezuela
}

\author{
Carmen G. Montaña ${ }^{1}$, Craig A. Layman ${ }^{2}$ and Donald C. Taphorn ${ }^{3}$
}

\begin{abstract}
Morichales are lowland streams in South American savannas with riparian forest dominated by the moriche palm (Mauritia flexuosa). We sampled littoral habitats from ten flooded vegetated patches (dominated by Mauritiella aculeate) and six sand banks in two months of the dry season (Feb-Mar 2005) in a stream in the savannas of Apure State, Venezuela. We collected samples that compromised 12,407 individual fishes of 107 species. Small-bodied fishes $(<100 \mathrm{~mm})$, representing diverse trophic and life history strategies, were abundant. The most abundant species were in the families Characidae and Cichlidae. Fish assemblages from flooded vegetated patches differed significantly from those on adjacent sand banks. High structural complexity along vegetated shoreline habitats of morichal streams likely contributes to species richness and affects assemblage composition.
\end{abstract}

Morichales ou buritizais são tipos de habitats de planícies de savana da América do Sul com vegetação ripária dominada por buritis (Mauritia flexuosa). Nós amostramos habitats litorâneos de dez fragmentos de buritis e seis bancos de areia durante dois meses de estação seca (Fev-Mar de 2005) em um curso de água de savana no Estado de Apure, Venezuela. Foram coletados 12.407 peixes pertencentes a 107 espécies. Espécies de pequeno porte $(<100 \mathrm{~mm})$, representando diversas estratégias de vida e categorias tróficas foram abundantes. As espécies mais abundantes pertenceram às famílias Characidae e Cichlidae. As assembléias de peixes dos fragmentos de vegetação inundada (buritis) diferiram significantemente daquelas dos bancos de areia adjacentes. A elevada complexidade estrutural ao longo dos habitats marginais dos riachos que corriam pelos buritizais provavelmente contribuiu para a riqueza de espécies e influenciou a composição das assembléias nesses sistemas.

Key words: Food availability, Habitat complexity, Predation, Prey, Refugia.

\section{Introduction}

Habitat complexity plays an integral role in community dynamics, ecological interactions, and coexistence of species (MacArthur, 1972; Gorman \& Karr, 1978). Structurally complex habitats generally support a higher diversity of organisms because they provide refugia from predators and substrate to support food resources (Crook \& Robertson, 1999). Structural components important in freshwater ecosystems include large woody debris derived from riparian vegetation, macrophytes, rocky outcroppings, and leaf litter.

In Neotropical freshwaters, some structurally-complex habitats have been relatively well-studied. For example, in the Amazon river the várzea, i.e., floodplain area submerged by water for at least a few months each year and dominated by plants adapted to hypoxic conditions, is one of the main habitat types contributing to the maintenance of Neotropical fish diversity (Goulding, 1980; Araujo-Lima et al., 1986; Petry et al., 2003). In floodplain rivers in the Venezuelan llanos (seasonally-inundated plains of the Orinoco), fish diversity has been shown to increase with greater habitat complexity, such as in rocky outcroppings and areas of high leaf litter (Willis et al., 2005; Arrington \& Winemiller, 2006).

The aquatic ecosystems known as morichales have received relatively little attention in Neotropical regions. Morichales are lowland gradient streams dominated by riparian forest of moriche palm (Mauritia flexuosa, Arecaceae). Mauritia palms are mostly restricted to lowlands of the Amazon and Orinoco basins along the shorelines of blackwater rivers (González-Boscán, 1987). A smaller relative, the morichito palm Mauritiella aculeata (Arecaceae) (Uhl \& Dransfield, 1987), also grows along the inundated margins of blackwater

${ }^{1}$ Ecology and Evolutionary Biology, Department of Wildlife \& Fisheries Sciences. Texas A\&M University, College Station, TX 77843-2258, USA.car1607@tamu.edu

${ }^{2}$ Florida International University. Marine Sciences Program. Department of Biological Sciences. North Miami, FL 33181. cal1634@yahoo.com ${ }^{3}$ Museo de Ciencias Naturales Guanare- BioCentro, Mesa de Cavacas via Biscucuy, Guanare, Portuguesa State, Venezuela 3310. taphorn@, gmail.com 
streams and rivers in the savanna regions (Camaripano-Venero \& Castillo, 2003). In Venezuela, morichal streams are more abundant in the Eastern Llanos of Venezuela and their fish fauna have not been well-studied (González-Boscán, 1987; Antonio-Cabre \& Lasso, 2003).

Here we describe fish assemblages from a small Neotropical morichal stream in southwestern Apure State, Venezuela, during two months of the dry season. We compared fish assemblages from flooded vegetated habitats (dominated by morichito palm) with those from sand banks, and discuss those characteristics of the vegetated areas that contribute to a rich fish fauna.

\section{Material and Methods}

\section{Study Site}

The study was conducted in Caño La Guardia, a moderate blackwater, floodplain morichal stream in the State of Apure, southwestern Venezuela $\left(6^{\circ} 32^{\prime} \mathrm{N} 67^{\circ} 24^{\prime} \mathrm{W}\right.$ and $6^{\circ} 49^{\prime} \mathrm{N}$ $67^{\circ} 37^{\prime} \mathrm{W}$ ) (Fig. 1). Caño La Guardia has a forested riparian zone, but open grassland dominates much of the drainage basin. In the wet season (May to October) the riparian forest and adjacent savanna are flooded, and organisms are dispersed widely throughout the floodplain (Lowe-McConnell, 1987; Rodriguez $\&$ Lewis, 1997). The dry season is associated with continuously falling water levels, forcing organisms into the main channel and associated littoral habitats (Arrington \& Winemiller, 2006).

We sampled two different littoral habitat types as part of this study: flooded vegetated areas dominated by stands of morichito palm and sandbanks. Vegetated habitats were defined as having $>90 \%$ of coverage by large woody debris derived from riparian vegetation (mainly morichito palms), grass, and leaf litter. These habitats had a moderate or slow current $(<0.05 \mathrm{~m} / \mathrm{s})$ and depth $\sim 1 \mathrm{~m}$. Sand banks were defined as sandy beaches in the main channel $(>95 \%$ coarse-sand substrate) with depth $\sim 1 \mathrm{~m}$ and moderate current $(<0.06 \mathrm{~m} / \mathrm{s})$.

\section{Sampling methods}

Sampling was conducted during February and March 2005 (dry season). For each of the two habitat types, sampling was conducted during daylight hours. Ten vegetated patches and six sand banks were sampled each month. In vegetated habitats, fish were sampled with a seine $(6.4 \times 1.2 \mathrm{~m}$ with 4 $\mathrm{mm}$ mesh) which was extended from shore at $\sim 1 \mathrm{~m}$ depth and hauled directly toward the morichal edge. The seine was passed three times in non-overlapping areas at each of the ten flooded sites. We also used a dipnet to collect fishes where access with the seine was difficult (due to submerged woody debris). Samples from both seine and dipnet were combined for vegetated patches.

On sand banks, the same seine was oriented parallel to the shoreline at $\sim 1 \mathrm{~m}$ depth and was hauled directly toward shore. At each site, three non-overlapping hauls were made and combined for one composite site sample. Dipnet samples were not taken from beaches, as these sites lacked structurally complex habitats and thus dipnet samples did not produce additional species. All fishes were identified to species, enumerated, and measured to the nearest $1.0 \mathrm{~mm}$ standard length (SL). Voucher specimens are archived in the Museo de Ciencias Naturales at UNELLEZ Guanare, Venezuela.

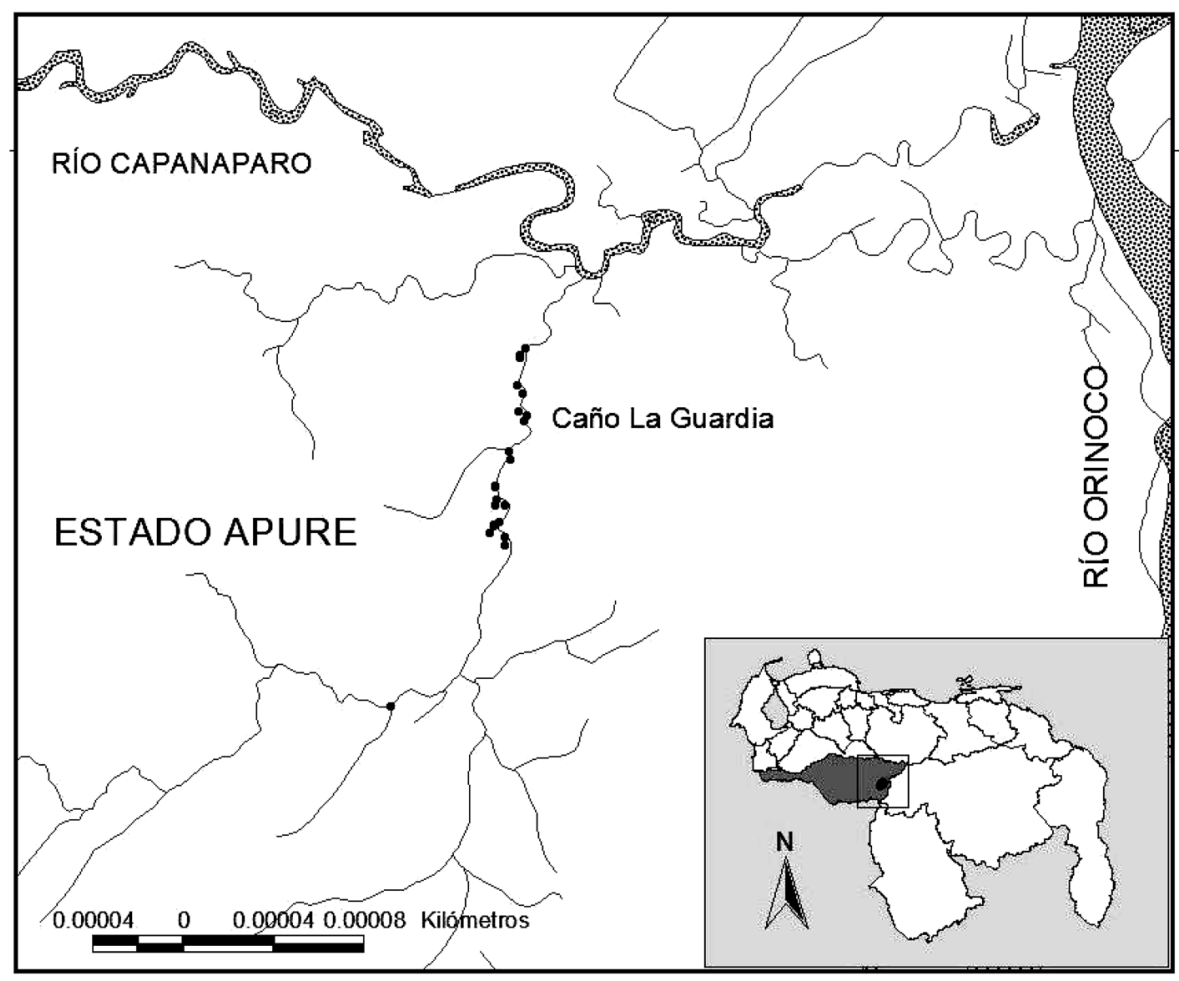

Fig. 1. Location of Caño La Guardia in the southwestern Apure State, Venezuela (Sampling sites are shown by black dots). 


\section{Statistical Analysis}

Fish assemblage structure was estimated for each habitat type and included: total specimens collected for each habitat $(\mathrm{N})$, species richness $(\mathrm{S})$, Shannon diversity index $\left(\mathrm{H}^{\prime}\right)$, and Shannon' equitability (Evenness, E) (Krebs, 1989). The Shannon diversity index is based on the formula: $\mathrm{H}^{\prime}=-p_{i}\left(\log _{10} p_{i}\right)$; where $p_{i}$ is the proportion of individuals found in the $i$ th species; and Evenness was calculated as $\mathrm{E}=$ $\mathrm{H}^{\prime} / \ln \mathrm{S}$. A $t$-test was used to test for significant differences in response variables between habitat types.

To compare fish assemblage similarity/dissimilarity among habitats based on species presence/absence, we used nonmetric multi-dimensional scaling (MDS). MDS constructs a 2-dimensional ordination in a manner that best represents relationships among samples in a similarity matrix (Clarke $\&$ Warwick, 2001). Similarity matrices were calculated using the Bray-Curtis similarity index (Bray \& Curtis, 1957). Analysis of similarities (ANOSIM; Clarke \& Warwick, 1994), a non-parametric analog of MANOVA, was used to test for differences in species composition among habitat categories. Similarity percentage analysis (SIMPER; Clarke \& Warwick, 1994) was performed to identify species accounting for significant differences.

\section{Results}

Collections resulted in total of 12,407 fish specimens, representing 29 families and 107 species (Table 1). The order Characiformes numerically dominated both habitat types, but there was a trend of more Perciformes and Siluriformes in vegetated sites (Table 2). The most diverse families were the Characidae with 32 species, followed by Cichlidae with 17 species. A total of 107 species were found in both habitats combined, with a total of 92 species in vegetated habitats and 66 on sand banks. Species richness was significantly higher in vegetated habitats (mean+/-SD; 30.2+/-5.9) than sand banks $(24.3+/-7.0)(t=2.57 ; \mathrm{df}=30 ; P=0.015)$. Measures of species diversity in vegetated habitats $\left(\mathrm{H}^{\prime}=1.57 ; \mathrm{E}=0.84\right)$ were higher than for sand banks $\left(H^{\prime}=1.50 ; E=0.74\right)$. Sand banks had the higher number of individuals collected $(\mathrm{t}=-4.26$; $\mathrm{df}$ $=30 ; \mathrm{p}<0.001$ ).

Assemblage composition of the two littoral habitats was significantly different (ANOSIM, $P<0.001$, $\mathrm{R}=0.9$; Fig. 2 ). Analysis of species' presence/absence showed significant differences between vegetated habitats and beaches. Fourty species were unique to vegetated habitats, whereas fifteen were unique to sand banks. Species typically associated with the vegetated habitats included small invertivorous cichlids (e.g., Apistogramma sp. A, Crenicichla aff. wallacii, and Mikrogeophagus ramirezi), small invertivorous doradid catfishes (e.g., Scorpiodoras heckelii and Amblydoras spp.) and small characids (e.g., Hemigrammus elegans and H. stictus). On beaches, the most common species were small-bodied pelagic characids (e.g., Moenkhausia spp., Bryconops spp., Hemigrammus spp.) that often display preferences for open water (Arrington \& Winemiller, 2006).

\section{Discussion}

Morichales are considered important systems for the maintenance of freshwater Neotropical fauna in lowland savannas (Marrero et al., 1997; Antonio-Cabre \& Lasso, 2003). The present work suggests that flooded vegetation habitats along morichal Caño La Guardia are important to a fish fauna composed largely of small-bodied cichlids, characins, lebiasinids, and silurids. Even though sand banks were characterized by a greater number of total individuals (which was perhaps a function of enhanced sampling efficiency on sand banks), species richness was significantly higher in vegetated habitats.

The importance of vegetated patches along streams has been well documented in temperate (Grenouillet \& Pont, 2001; Growns et al., 2003) as well as tropical regions (Araujo-Lima et al. 1986; Petry et al., 2003). Submerged macrophytes, woody debris, and other vegetated structures produce considerable variation in structural complexity in littoral zones and provide habitat for young fishes that use the submerged roots as refugia from predation and for foraging. These two factors are probably responsible for the higher species richness found in vegetated habitats along morichal La Guardia.

Dense stands of vegetated patches may be essential for survival and maintenance of populations of prey taxa that need to avoid predators, especially during the dry season when predator densities increase (Lowe-McConnell, 1987; Layman \& Winemiller, 2004). Submerged vegetation is known to mediate predator-prey relationships via increased structural complexity (Crowder \& Cooper, 1979). For example, high macrophyte or submerged woody density can decrease predator efficiency by reducing visual contact with the prey (Werner et al., 1983). Despite the fact that we did not quantify large predator densities in this particular study, large-bodied piscivores such as Cichla spp., Hydrolycus spp., and Serrasalmus spp. are abundant (Montaña

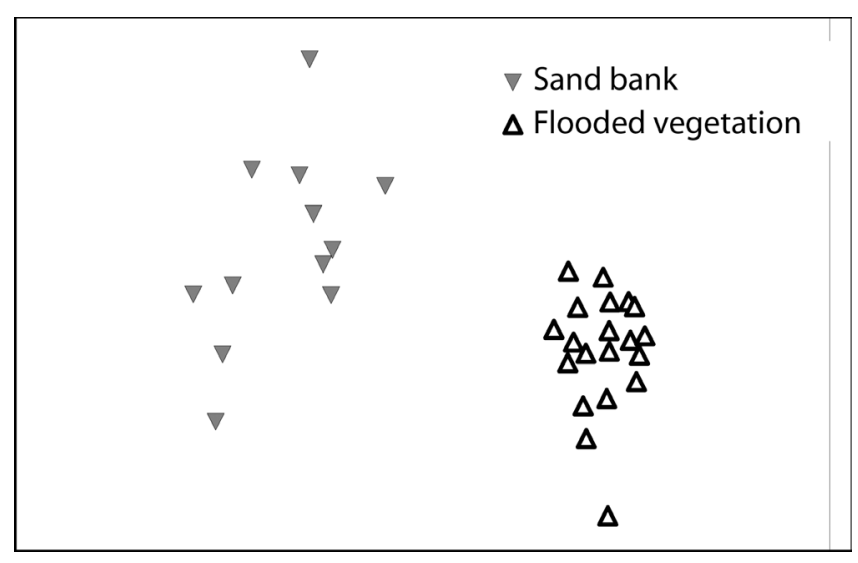

Fig. 2. Non-multi-dimensional scaling (MDS) ordination depicting similarity/dissimilarity of fish assemblages from flooded vegetation (open triangles) and sand bank habitats (inverted closed triangles). Each symbol represents one sampling site. Relative distance among symbols represents the relative similarity/dissimilarity of assemblage composition from the site based on presence/absence data. 
Table 1. Species list with the total of individuals caught for each littoral habitat in Caño La Guardia during the dry season.

\begin{tabular}{|c|c|c|}
\hline Order/Family/Genus species & Flooded vegetated & Sand bank \\
\hline \multicolumn{3}{|l|}{ CLUPEIFORMES } \\
\hline \multicolumn{3}{|l|}{ Engraulidae } \\
\hline Amazonsprattus scintilla & - & 146 \\
\hline Anchovia sp. & 1 & 121 \\
\hline Anchoviella sp. & - & 119 \\
\hline \multicolumn{3}{|l|}{ CHARACIFORMES } \\
\hline \multicolumn{3}{|l|}{ Acestrorhynchidae } \\
\hline Acestrorhynchus microlepis & - & 11 \\
\hline Acestrorhynchus minimus & - & 12 \\
\hline \multicolumn{3}{|l|}{ Characidae } \\
\hline Brittanichthys sp. & 14 & - \\
\hline Brycon falcatus & 2 & 18 \\
\hline Bryconamericus sp. & 27 & 70 \\
\hline Bryconops alburnoides & 5 & 130 \\
\hline Bryconops caudomaculatus & 8 & 216 \\
\hline Bryconops giacopinii & 4 & 19 \\
\hline Charax condei & 59 & - \\
\hline Gnathocharax steindachneri & 30 & - \\
\hline Hemigrammus analis & 77 & 258 \\
\hline Hemigrammus barrigonae & 152 & \\
\hline Hemigrammus elegans & 579 & 24 \\
\hline Hemigrammus micropterus & 111 & 245 \\
\hline Hemigrammus microstomus & 257 & - \\
\hline Hemigrammus rhodostomus & 33 & - \\
\hline Hemigrammus schmardae & 48 & 150 \\
\hline Hemigrammus sp. A & 139 & 420 \\
\hline Hemigrammus sp. B & 134 & 215 \\
\hline Hemigrammus stictus & 467 & - \\
\hline Hemigrammus vorderwinkleri & 183 & 248 \\
\hline Heterocharax leptogrammus & 6 & - \\
\hline Iguanodectes spilurus & 66 & 19 \\
\hline Microschemobrycon callops & 2 & 255 \\
\hline Microschemobrycon casiquiare & 12 & 391 \\
\hline Moenkhausia copei & 199 & 758 \\
\hline Moenkhausia lepidura & 7 & 223 \\
\hline Moenkhausia oligolepis & 3 & - \\
\hline Moenkhausia sp. A & 78 & 193 \\
\hline Moenkhausia sp. B & 5 & 56 \\
\hline Mytennis hypsauchen & 1 & 18 \\
\hline Pristobrycon striolatus & 3 & 1 \\
\hline Serrabrycon magoi & 229 & 17 \\
\hline Serrasalmus manиeli & 3 & 6 \\
\hline \multicolumn{3}{|l|}{ Ctenoluciidae } \\
\hline Boulengerella cuvieri & - & 3 \\
\hline \multicolumn{3}{|l|}{ Crenuchidae } \\
\hline Ammocryptocharax elegans & 24 & - \\
\hline Characidium longum & 1 & 317 \\
\hline Characidium sp. & 150 & 365 \\
\hline Elachocharax pulcher & 203 & - \\
\hline Microcharacidium gnomus & 19 & - \\
\hline \multicolumn{3}{|l|}{ Curimatidae } \\
\hline Cyphocharax oenas & 25 & 45 \\
\hline Cyphocharax spilurus & 91 & 109 \\
\hline \multicolumn{3}{|l|}{ Erythrinidae } \\
\hline Hoplias malabaricus & 21 & - \\
\hline Hoplerythrinus unitaeniatus & 13 & - \\
\hline \multicolumn{3}{|l|}{ Gasteropelecidae } \\
\hline Carnegiella marthae & 105 & - \\
\hline \multicolumn{3}{|l|}{ Lebiasinidae } \\
\hline Copella metae & 105 & - \\
\hline Copella nattereri & 5 & - \\
\hline Nannostomus eques & 245 & 12 \\
\hline Nannostomus unifasciatus & 167 & 24 \\
\hline Pyrrhulina lugubris & 131 & 4 \\
\hline Hemiodontidae & & \\
\hline Anodus orinocensis & - & 8 \\
\hline Argonectes longiceps & 3 & 11 \\
\hline Hemiodus gracilis & 10 & 193 \\
\hline Hemiodus semitaeniatus & - & 33 \\
\hline Hemiodus unimaculatus & 2 & 12 \\
\hline Prochilodontidae & & \\
\hline Semaprochilodus kneri & - & 5 \\
\hline
\end{tabular}

\begin{tabular}{|c|c|c|}
\hline \multicolumn{3}{|l|}{$\begin{array}{l}\text { CYPRINODONTIFORMES } \\
\text { Poeciliidae }\end{array}$} \\
\hline Fluviphylax obscurus & 28 & 7 \\
\hline \multicolumn{3}{|l|}{ GYMNOTIFORMES } \\
\hline Gymnotus carapo & 2 & - \\
\hline \multicolumn{3}{|l|}{ Hypopomidae } \\
\hline Brachyhypopomus sp. & 3 & - \\
\hline Hypopygus neblinae & 4 & - \\
\hline Microsternarchus bilineatus & 48 & - \\
\hline \multicolumn{2}{|l|}{ Rhamphichthyidae } & - \\
\hline $\begin{array}{l}\text { Gymnorhamphichthys rondoni } \\
\text { Sternopygidae }\end{array}$ & 1 & 1 \\
\hline Eigenmannia virescens & 1 & - \\
\hline \multicolumn{2}{|l|}{ PERCIFORMES } & \\
\hline Acaronia vultuosa & 91 & - \\
\hline Aequidens diadema & 76 & - \\
\hline Apistogramma hoignei & 284 & 16 \\
\hline Apistogramma sp. & 349 & 59 \\
\hline Biotecus dicentrarchus & 5 & 42 \\
\hline Biotodoma wavrini & 8 & 143 \\
\hline Bujurquina sp. & 14 & - \\
\hline Cichla orinocensis & - & 5 \\
\hline Cichla temensis & 4 & 6 \\
\hline Crenicichla aff. wallacii & 106 & 82 \\
\hline Geophagus abalios & - & 47 \\
\hline Geophagus dicrozoster & - & 38 \\
\hline Geophagus sp. (juveniles) & 4 & 98 \\
\hline Heros aff. severus & 78 & - \\
\hline Mesonauta insignis & 15 & - \\
\hline Mikrogeophagus ramirezi & 61 & - \\
\hline Satanoperca mapiritensi & 30 & 12 \\
\hline \multirow{2}{*}{\multicolumn{3}{|c|}{ Eleotridae }} \\
\hline & & \\
\hline Microphilypnus amazonicus & 15 & 27 \\
\hline \multicolumn{3}{|l|}{$\begin{array}{l}\text { Polycentridae } \\
\text { Pas }\end{array}$} \\
\hline Monocirrhus polyacanthus & 2 & - \\
\hline \multicolumn{3}{|l|}{ SILURIFORMES } \\
\hline \multicolumn{3}{|l|}{ Auchenipteridae } \\
\hline Centromochlus concolor & 58 & 137 \\
\hline \multicolumn{3}{|l|}{ Callichthyidae } \\
\hline Corydoras sp. A & 15 & - \\
\hline \multicolumn{3}{|l|}{ Cetopsidae } \\
\hline Pseudocetopsis aff. minutus & 2 & - \\
\hline \multicolumn{3}{|l|}{ Doradidae } \\
\hline Acanthodoras sp. & 8 & - \\
\hline Amblydoras affinis & 15 & - \\
\hline Amblydoras gonzalezi & 27 & - \\
\hline Physopyxis ananas & 89 & - \\
\hline Scorpiodoras heckelii & 281 & 56 \\
\hline Heptapteridae & & \\
\hline Goeldiella eques & 1 & - \\
\hline Imparfinis sp. & - & 31 \\
\hline Pimelodella sp. & - & 8 \\
\hline Loricariidae & & \\
\hline Panaque maccus & 2 & - \\
\hline Parotocinclus sp. & 4 & - \\
\hline Pterygoplichthys gibbiceps & 3 & - \\
\hline Rineloricaria sp. & 1 & 13 \\
\hline Pseudopimelodidae & & \\
\hline Microglanis iheringi & 2 & - \\
\hline Trichomycteridae & & \\
\hline Ochmacanthus alternus & 5 & 31 \\
\hline SYNBRANCHIFORMES & & \\
\hline Synbranchidae & & \\
\hline Synbranchus marmoratus & 7 & 4 \\
\hline PLEURONECTIFORMES & & \\
\hline Achiridae & & \\
\hline Hypoclinemus mentalis & - & 3 \\
\hline
\end{tabular}


Table 2. Fish orders collected in Caño La Guardia and fish assemblage attributes for each sampled habitat type.

\begin{tabular}{lcccccc}
\hline & \multicolumn{3}{c}{ Flooded vegetation } & \multicolumn{3}{c}{ Sand bank } \\
\cline { 2 - 7 } & $\mathrm{S}$ & Families & $\mathrm{N}$ & $\mathrm{S}$ & Families & $\mathrm{N}$ \\
\hline Clupeiformes & 1 & 1 & 1 & 3 & 1 & 386 \\
Characiformes & 51 & 7 & 4264 & 38 & 7 & 5117 \\
Siluriformes & 14 & 8 & 513 & 8 & 5 & 276 \\
Gymnotiformes & 7 & 4 & 62 & 1 & 1 & 1 \\
Cyprinodontiformes & 1 & 1 & 28 & 1 & 1 & 7 \\
Synbranchiformes & 1 & 1 & 7 & 1 & 1 & 4 \\
Perciformes & 17 & 3 & 1147 & 13 & 2 & 593 \\
Pleuronectiformes & & & & 1 & 1 & 1 \\
\hline Total & 92 & 25 & 6022 & 66 & 19 & 6385 \\
\hline
\end{tabular}

et al., Unpublished data), similar to the high densities of predators of the nearby Cinaruco River (Layman \& Winemiller, 2004; Layman \& Winemiller, 2005; Layman et al., 2005).

In structurally complex habitats, specialist species also can exploit specific food resources to which they are morphologically or physiologically adapted to utilize (Willis et al., 2005). For example, in vegetated patches we found a relatively high abundance of small cichlids and doradid catfishes with different body shapes and feeding habits (e.g., Apistgramma hoignei, Physopyxis ananas). But small omnivorous characids with less-diversified body morphologies (Characidae), such as tetras of the genera Moenkhausia spp. and Hemigrammus spp., dominated open and shallow beaches. Littoral habitats containing woody debris and leaf litter also might support higher primary and secondary productivity which provides fishes with more foraging opportunities on a larger variety of substrates (Benke et al., 1985; Crook \& Robertson, 1999). Relationships between fish structure and macroinvertebrate assemblages have been associated with habitat heterogeneity (Angermeier \& Karr, 1984). Although we did not evaluate communities of small invertebrates in this study, it was apparent that vegetated patches contained a high abundance of shrimps and other macroinvertebrates.

In summary, vegetated patches along morichal Caño La Guardia are suitable for a large number of species with a wide range of trophic strategies and life histories (Machado-Allison, 1990; Winemiller, 1989). Since this research was conducted only during the dry season, further research may reveal additional temporal patterns of fish utilization of morichales. Our results suggest that conservation of morichal ecosystems may be an essential part of the conservation of fish assemblages in the Neotropics.

\section{Acknowledgements}

Jay Roff provided logistical and economical support through the La Guardia Camp. Isidoro Garcia and family provided valuable field assistance. Stuart Willis, Douglas Rodriguez, Albrey Arrington, and Kirk Winemiller provided helpful comments on the manuscript. Fish collections were made with scientific fishing permit 000074 issued by the Instituto Nacional de Acuicultura y Pesca (INAPESCA) of the Republica Bolivariana de Venezuela. This is contribution 157 of the Tropical Biology Program at Florida International University.

\section{Literature Cited}

Angermeier, P. L. \& J. R. Karr. 1984. Relationships between woody debris and fish habitat in small warmwater stream. Transactions of the American Fisheries Society, 113: 716-726.

Antonio-Cabre, M. E. \& C. A. Lasso. 2003. Los peces del Morichal Largo estados Anzoategui y Monagas cuenca del Río Orinoco, Venezuela. Memorias de la Fundación La Salle Ciencias Naturales, 156: 5-118.

Araujo-Lima, C. A., L. Portugal \& E. Ferreira. 1986. Fish-macrophyte relationship in Anavilhanas Archipelago, a black water system in the central Amazon. Journal of Fish Biology, 29: 1-11.

Arrington, D. A. \& K. O. Winemiller. 2006. Habitat affinity, the seasonal flood pulse, and community assembly in littoral zone of a Neotropical floodplain river. Journal of the North American Benthological Society, 25(1): 126-141.

Benke, A. C., R. L. Henry III, D. M. Gillespie \& R. J. Hunter. 1985. Importance of snag habitat for animal production in southeastern streams. Fisheries, 10: 8-13.

Bray, J. R. \& J. C. Curtis. 1957. An ordination of the upland forest communities of southern Wisconsin. Ecological Monographs, 27: 325-349.

Camaripano-Venero, B. \& A. Castillo. 2003. Catálogo de espermatofitas del bosque estacionalmente inundable del Rio Sipapo, estado Amazonas, Venezuela. Acta Botanica Venezuelica, 26(2): 125-230.

Clarke, K. R. \& W. M. Warwick. 1994. Similarity-based testing for community pattern: the 2-way layout with no replication. Marine Biology, 118: 167-176.

Clarke, K. R. \& W. M. Warwick. 2001. Change in marine communities: an approach to statistical analysis and interpretation. PRIMER-E Ltd, Plymouth, UK. 91p.

Crook, D. A. \& A. I. Robertson. 1999. Relationships between riverine fish and woody debris: implications for lowland rivers. Marine and Freshwater Research, 50: 441-953.

Crowder, L. \& W. Cooper. 1979. Structurally complexity and fishprey interactions in ponds: a point of view. Pp. 2-10. In: Johnson, D. \& R. Stein (Eds.). Response of fish to habitat structure in standing water. North Central Division American Fisheries Society, Special publication 6, North Central Division, American Fisheries Society, Maryland, 77p.

González-Boscán, V. 1987. Los morichales de los llanos orientales. Un enfoque ecológico. Caracas, Ediciones Corpoven. 85p.

Gorman, O. T. \& J. R. Karr. 1978. Habitat structure and stream fish communities. Ecology, 59: 507-515.

Goulding, M. 1980. The Fishes and the forest: Explorations in the Amazonian Natural History. Berkeley, University of California Press. 265p.

Grenouillet, G. \& D. Pont. 2001. Juvenile fishes in macrophyte beds: influence of food resources, habitat structure and body size. Journal of Fish Biology, 59: 939-959

Growns, I., P. C. Gehrke, K. L. Astles \& D. A. Pollard. 2003. A comparison of fish assemblages associated with different riparian vegetation types in the Hawkesbury-Nepean River system. Fisheries Management and Ecology, 10: 209-220.

Krebs, C. J. 1989. Ecological methodology. Harper and Row, New York. 654p.

Layman, C. A., R. B. Langerhans \& K. O. Winemiller. 2005. Do species traits characterize changes in fish assemblage composition following commercial netting? Canadian Journal of Fisheries and Aquatic Sciences, 62: 1-9. 
Layman, C. A. \& K. O. Winemiller. 2004. Sized-based responses of prey to piscivore exclusion in a species rich Neotropical river. Ecology, 85(5): 1311-1320.

Layman, C. A. \& K. O. Winemiller. 2005. Patterns of segregation among large fishes in a Venezuelan floodplain river. Neotropical Ichthyology, 3(1): 103-109.

Lowe-McConnell, R. H. 1987. Ecological aspects of seasonality in fishes of tropical waters. Symposia of the Zoological Society of London, 44: 219-241.

MacArthur, R. H. 1972. Geographical Ecology: Patterns in the distribution of species. Harper \& Row, New York, 268p.

Machado-Allison, A. 1990. Ecología de los peces de las áreas inundables de los Llanos de Venezuela. Interciencia, 15: 411:423.

Marrero, C., A. Machado-Allison, V. González, J. Velásquez \& D. Rodríguez-Olarte. 1997. Los morichales del oriente de Venezuela. Su importancia en la distribución y ecología de los componentes de la ictiofauna dulceacuicula regional. Acta Biológica de Venezuela, 17(4): 65-79.

Petry, P., P. Baley \& F. Markle. 2003. Relationships between fish assemblages, macrophytes and environmental gradients in the Amazon River floodplain. Journal of Fish Biology, 63: 547-579.
Rodríguez, M. A. \& W. M. Jr. Lewis. 1997. Structure of fish assemblages along environmental gradients in floodplain lakes of the Orinoco River. Ecological Monographs, 67: 109-128.

Uhl, N. W. \& J. Dransfield. 1987. Genera Palmarum: a classification of palms based on the work of Harold E. Moore Jr. Allen Press, Kansas, 610p.

Werner, E., D. Hall, D. Laughlin, D. Wagner, L. Wilsmann \& F. Funk. 1977. Habitat partitioning in a freshwater fish community. Journal of the Fisheries Research Board of Canada, 34: 360-370.

Willis, S., K. O. Winemiller \& H. López-Fernández. 2005. Habitat structural complexity and morphological diversity of fish assemblages in a Neotropical floodplain river. Oecologia, 142: 284-295.

Winemiller, K. O. 1989. Patterns of variation in life history among South American fishes in seasonal environments. Oecologia, 81: $225-241$.

Accepted July 2008

Published December 22, 2008 